\title{
Body types of Aberdeen Angus bulls and their relationship with meat production
}

\author{
Mukhamed Shakhmurzov ${ }^{1}$, Anatoliy Shevkhuzhev², Vladimir Pogodaev²,*, Yusupzhan \\ Yuldashbaev $^{3}$, and Shamurat Kherremov ${ }^{4}$ \\ ${ }^{1}$ Kabardino-Balkarian State Agricultural University named after V. M. Kokov, Lenin Avenue, 1V, \\ 360030 Nalchik, Russia \\ ${ }^{2}$ Federal State Budgetary Scientific Institution North Caucasian Federal Scientific Agrarian Center, \\ Nikonova Str., 49, 546241 Mikhailovsk, Russia \\ ${ }^{3}$ Russian State Agrarian University - Moscow Agricultural Academy named after K. A. Timiryazev, \\ Timiryazevskaya St., 49, 127550 Moscow, Russia \\ ${ }^{4}$ Union of Industrialists and Entrepreneurs of Turkmenistan, Atamurad Niyazova Av., 174, 744000 \\ Ashgabat, Turkmenistan
}

\begin{abstract}
The study results of Aberdeen-Angus breed bull meat production, depending on the body type, are presented. The first group consisted of bulls descended from stud bulls of large tall type, the second group consisted of bulls descended from stud bulls of the small compact type. It was determined that at the age of 18 months, bulls from large-type parents reached a weight of $442 \mathrm{~kg}$, and from small-type parents - $413 \mathrm{~kg}$. The first group bulls had a higher pre-slaughter weight by $31.4 \mathrm{~kg}$ and heavy carcasses compared to the second group bulls by $28.3 \mathrm{~kg}$ or $13.5 \%$ $(\mathrm{P}>0.99)$. The first group bulls, being higher-legged, produced carcasses with a higher bone content (by $4.08 \mathrm{~kg}$ ) during slaughter compared to the second group. In their carcasses, there was $4.52 \mathrm{~kg}$ of boneless meat per 1 $\mathrm{kg}$ of bones, while in the second group carcasses - $5.03 \mathrm{~kg}$. However, in general, when boning semi-carcasses of the first group, more boneless meat was obtained, by $9.9 \mathrm{~kg}$. or by $11.72 \%(\mathrm{P}>0.99)$ compared with the second group.
\end{abstract}

\section{Introduction}

The main purpose of beef cattle breeding in the coming decades is to increase production volumes and improve the quality of the products obtained enhance the competitive capacity of the industry $[1,2]$.

Therefore, the development of regional programs for the rational use of breed and feed resources to increase the quantity and improve the quality of the produced beef is an urgent goal $[2,3,4]$.

The growing demand for meat as a food product and the need to obtain it with the lowest cost of feed and funds put forward as the main task of breeding in beef cattle breeding - development of animals with high vigor, good feed pay, capable of reaching

* Corresponding author: pogodaev_1954@mail.ru 
large livestock by the age of 15-18 months, with a high slaughter yield and good quality meat indicators [5-8].

In this regard, in beef cattle breeding there is a tendency towards a transition from the extreme compact (solid) type with a short and square body on low legs to a type that is larger in live weight and well-defined meat forms $[9,10]$.

The Aberdeen-Angus breed, widespread in Russia, including in Karachay-Cherkessia, belongs to one of the world's best meat breeds [11-14]. However, in the last two decades, this breed has also developed towards the formation of a relatively small, but very early maturing type. In this regard, there is a need for a certain breed restructuring, establishment of the most desirable and promising type, improvement of breeding and rearing pedigree young stock methods.

The study purpose was Aberdeen-Angus breed bull meat production, depending on the body type.

\section{Materials and Methods}

In studies on cattle meat production, much attention is paid to meat qualities, based on the assessment of its distribution in the carcass.

Hammer LLC of Karachay-Cherkessia conducted the experiment: from the offspring of 4 large bulls and 3 small bulls of the Aberdeen-Angus breed, 14 bulls were selected in each group.

The fathers of the first group bulls had a higher level of live weight compared to the fathers of the second group bulls (by $80 \mathrm{~kg}$ ) and differed from them in high-leggedness, less broad body and massiveness. The mothers of the first group bulls also had a higher live weight (by $49 \mathrm{~kg}$ ) in comparison with the mothers of the second group bulls, the body type differences were insignificant.

Immediately after weaning, they were placed on control rearing. The average age of the first group bulls at weaning was 8 months 22 days, and the second group bulls -8 months 20 days.

Selection according to the principle of analogs in experimental groups was based on live weight, age, health status and origin.

The first group consisted of bulls descended from stud bulls of large tall type, the second group consisted of bulls descended from stud bulls of the small compact type.

The conditions of bull feeding and keeping in experimental groups were the same and corresponded to the farm rearing system.

The feeding level was designed to obtain an average daily gain of 650-750 $\mathrm{g}$ in the period from 8 to 12 months and 750-850 g from 12 to 18 months of age.

The study of the growth of experimental animals was performed by weighing, when setting up for experiment, at the age of 12,15 and 18 months.

To get a more complete picture of the growth intensity in experimental animals, the relative growth rate was calculated.

To study the quantity and quality of meat products of experimental animals, a control slaughter of young animals was performed at the age of 18 months. For control slaughter, 3 of the most typical animals of the same age were selected from each group.

he slaughter was carried out at the Circassian meat-packing plant LLC Kavkaz-Myaso according to All-Russian Research Institute of Metrological Service and Federal Research Center for Animal Husbandry named after Academy Member L.K. Ernst procedures.

To study the morphological composition of the carcasses, left semi-carcasses were divided into five cuts with their subsequent boning.

To characterize full meatiness of the carcasses, the following measurements were taken: 
1. Body length in $\mathrm{cm}$ - from the sacrum extreme anterior point on the cut to the middle of the first rib anterior edge.

2. Thigh length in $\mathrm{cm}$ - from the highest point of the heel hock joint to sacrum anterior point.

3. Carcass length in $\mathrm{cm}-$ body length + thigh length.

4. Thigh circumference in $\mathrm{cm}$ - in a plane $60 \%$ apart from the beginning of the thigh length measurement line and perpendicular to this length.

Coefficients "K1" of the carcass full meatiness and "K2" of the thigh were calculated using the following formulas:

$$
\begin{aligned}
& \text { Coefficient K1 }=\frac{\text { Carcass weight } * 100}{\text { Carcass length }} \\
& \text { Coefficient K2 }=\frac{\text { Thigh girth } * 100}{\text { Thigh length }}
\end{aligned}
$$

The obtained experimental material was biometrically processed using the Microsoft Office 2007 software package.

\section{Study Results}

The live weight dynamics is one of the main indicators in the study of animal meat production.

It was found that the first group bulls exceeded the second group equivalents in live weight (FIG.1). The confidence criterion value, calculated for the difference in live weight is $t_{d}=3.26$. It indicates the confidence of the obtained difference $(P>0.99)$.

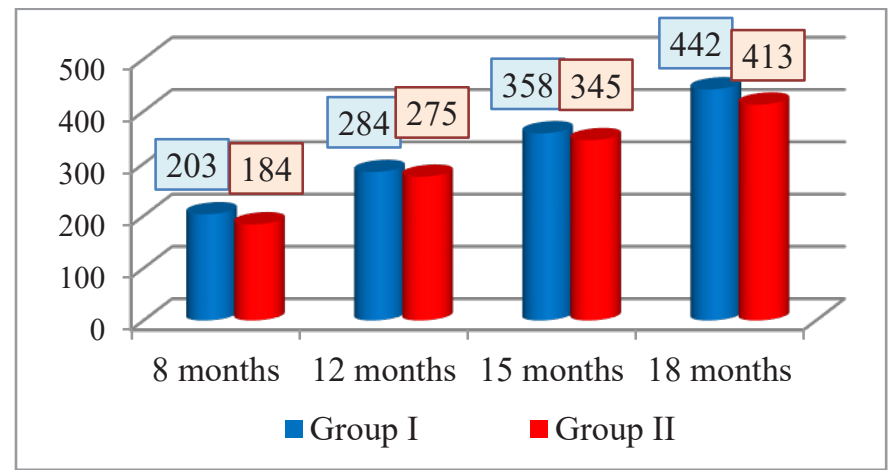

Fig. 1. The live weight dynamics of experimental bulls.

The presented data on changes in the average daily gain in live weight of experimental bulls indicate that, during the suckling period, the first group bulls demonstrated higher gains than the second group bulls (FIG. 2). 


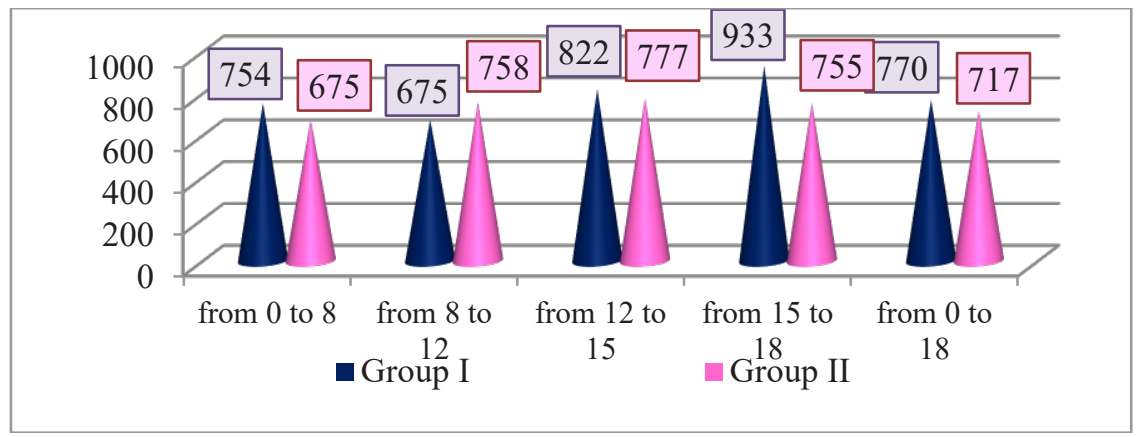

Fig. 2. Change in average daily gains of experimental bulls by growth periods.

The reason for this is the better milk yield of mothers (larger ones in the first group), because the conditions of feeding and keeping cows with suckling calves were approximately the same, the heritability of live weight at this age was rather low $(\mathrm{h}=0.28$ $0.30)$.

After weaning and up to 12 months of age, the first group bulls grew slightly worse and demonstrated average daily gains $11 \%$ lower than the second group bulls. During this period, the difference in average body weight between groups decreased from $10.3 \%$ at weaning to $3.3 \%$ at 12 months of age.

Starting from the age of 13 months, the second group bulls grew somewhat more slowly than the first group bulls, which until the end of the experiment had higher average daily gains. Over the entire experimental period, the first group bulls demonstrated average daily gains by $4.4 \%$ higher than the second group bulls and at the end of the experiment had a large live weight of $29 \mathrm{~kg}$, or $7.02 \%$.

Data on slaughter yield, carcass quality and meat amount were determined based on control slaughter at the end of the experiment when the bulls reached the age of 18 months.

The first group bulls had a well-pronounced tall body type, the second group bulls were distinguished by their low legs and compactness. The average age of the first group bulls was 526 days, the removable weight was $436 \mathrm{~kg}$, the second group bulls were 530 days and $406 \mathrm{~kg}$, respectively.

Before being sent to the meat packing plant, the animals were weighed, upon arrival and put on a 24-hour fasting period, during which they were watered. Before being taken to the slaughterhouse, the animals were weighed again and their lifetime fatness was determined. All animals for slaughter, when accepted at the meat packing plant, were classified as having the highest nutritional status.

The slaughter results showed (Table 1) that the first group bulls had a higher preslaughter weight by $31.4 \mathrm{~kg}$ and heavy carcasses compared to the second group bulls by $28.3 \mathrm{~kg}$ or $13.5 \%(\mathrm{P}>0.99)$.

Table 1. Control slaughter results of experimental bulls $(n=3)$.

\begin{tabular}{|c|c|c|}
\hline Indicators & Group 1 & Group 2 \\
\hline Preslaughter weight, $\mathrm{kg}$ & $408.4 \pm 3.74$ & $377.0 \pm 4.20$ \\
\hline Carcass weight, $\mathrm{kg}$ & $238.0 \pm 2.95$ & $209.7 \pm 3.02$ \\
\hline Interior fat weight, $\mathrm{kg}$ & $9.9 \pm 0.14$ & $11.7 \pm 0.16$ \\
\hline Internal fat yield, \% & $3.0 \pm 0.03$ & $3.1 \pm 0.03$ \\
\hline Slaughter weight, $\mathrm{kg}$ & $247.9 \pm 3.45$ & $221.4 \pm 3.52$ \\
\hline Carcass yield, \% & $58.27 \pm 0.25$ & $55.62 \pm 0.23$ \\
\hline Slaughter yield, \% & $60.71 \pm 0.28$ & $58.73 \pm 0.27$ \\
\hline
\end{tabular}


There were some differences in the internal fat yield. The first group bulls had a higher carcass yield (by 2.65 abs.\%) and a lower content of internal fat by $1.8 \mathrm{~kg}$.

By the slaughter weight, the first group bulls surpassed their equivalents by $26.5 \mathrm{~kg}(\mathrm{P}>$ 0.99), and by the slaughter yield, respectively, by $1.98 \mathrm{abs} . \%$.

Offals of the first group bulls had a larger weight (Table 2). However, in relation to the pre-slaughter weight, there were almost no differences between the groups or they were very insignificant (intestines, head, legs).

Table 2. Weight and yield of offal, fat and skins.

\begin{tabular}{|c|c|c|c|c|}
\hline \multirow{2}{*}{ Name of } & \multicolumn{2}{|c|}{ Group 1 } & \multicolumn{2}{c|}{ Group 2 } \\
\cline { 2 - 5 } & $\begin{array}{c}\text { Weight } \\
(\mathrm{kg})\end{array}$ & $\begin{array}{c}\text { \% to live } \\
\text { weight }\end{array}$ & $\begin{array}{c}\text { Weight } \\
(\mathrm{kg})\end{array}$ & $\begin{array}{c}\text { \% to live } \\
\text { weight }\end{array}$ \\
\hline Head & 16.0 & 3.81 & 14 & 3.71 \\
\hline Legs & 8.16 & 1.94 & 7.1 & 1.88 \\
\hline Lung & 2.58 & 0.60 & 2.36 & 0.62 \\
\hline Heart & 1.97 & 0.47 & 1.67 & 1.44 \\
\hline Liver & 5.3 & 1.26 & 4.86 & 1.29 \\
\hline Kidney & 1.10 & 0.26 & 1.10 & 0.29 \\
\hline Spleen & 1.2 & 0.28 & 0.88 & 0.22 \\
\hline $\begin{array}{c}\text { Intestine without } \\
\text { contents }\end{array}$ & 3.96 & 0.94 & 4.50 & 1.19 \\
\hline Total fat & 9.86 & 2.35 & 11.73 & 3.11 \\
\hline Incl. caul fat & 2.63 & 0.62 & 2.70 & 0.72 \\
\hline suet fat & 1.13 & 0.27 & 1.53 & 0.41 \\
\hline intestinal & 4.00 & 0.95 & 4.70 & 1.25 \\
\hline mouse round & 2.10 & 0.50 & 2.80 & 0.74 \\
\hline Hide & 30.6 & 7.28 & 29.3 & 7.77 \\
\hline
\end{tabular}

There is no objective method to evaluate carcass quality and production conditions. Carcasses are evaluated mainly by the presence of fatty deposits on their surface. Finally, such an important indicator of the meat carcass quality, as the development of muscle tissue, is not sufficiently taken into account as there are no objective characteristics.

To characterize the full meatiness of carcasses, their measurements have recently been used. As a result of a number of studies in our country and abroad, a relationship was established between bone weight and carcass length $(\mathrm{r}=0.78)$. The meat layer thickness, measured at the first rib middle, is related to the total weight of the meat in the carcass $(\mathrm{r}=$ 0.91). A direct relationship was established between the fore shank girth and the weight of bones in the semi-carcass, between the thigh girth and boneless meat yield during carcass boning.

To determine the full meatiness of the carcass, the size and quality of fat coating during the control slaughter, their expert eye assessment was performed and the main measurements were taken.

All carcasses of killed bulls are distinguished by well-developed muscles, which was especially noticeable in the thigh, waist and back. Fat coating on carcasses of both the first and second groups was thin, uniform, with gaps in the area of shoulder blades and ribs. The fat layer thickness at the last rib level was 1-2 mm. The carcasses obtained from the slaughter of the second group bulls had a slightly better coating (3.13 points) in comparison with the first group (2.74 points).

To characterize the full meatiness of carcasses, they were measured (Table 3 ). 
Table 3. Carcass measurements and assessment of their full meatiness.

\begin{tabular}{|c|c|c|}
\hline $\begin{array}{c}\text { Carcass } \\
\text { measurements }\end{array}$ & Group 1 & Group 2 \\
\hline Body length & $103.0 \pm 1.56$ & $98.7 \pm 1.48$ \\
\hline Femoral length & $90.7 \pm 0.69$ & $83.3 \pm 0.74$ \\
\hline Thigh girth & $94.3 \pm 0.76$ & $90.3 \pm 0.68$ \\
\hline Carcass length & $193.7 \pm 2.57$ & $182.0 \pm 2.63$ \\
\hline Coefficients: $\mathrm{K}_{1}$ & $120 \pm 0.88$ & $115 \pm 0.80$ \\
\hline $\mathrm{K}_{2}$ & $104 \pm 0.64$ & $108 \pm 0.70$ \\
\hline
\end{tabular}

If the value of " $\mathrm{K}_{1}$ " is higher than 100 , i.e. the carcass weight exceeds its length, it indicates very good meatiness. The correlation coefficient between " $\mathrm{K}_{1}$ " indicators and meat yield indicators is 0.84 .

In our experience, the full meatiness of carcasses was quite high, both in the first and in the second group. In the first group, the full meatiness of carcasses was slightly higher, since they had a large eight (by 12\%) and length (by 6\%). The second group carcasses had a higher indicator in terms of the thigh, it was shorter and relatively wider. The differences in the measurements of the carcasses were a reflection of the body type of the killed animals.

The study of the morphological composition of the carcasses of the experimental animals was performed using by boning of semi-carcasses, resulted in the following: the weight of meat, fat, bones and tendons.

The boning of semi-carcasses showed that the first and second group carcasses had some differences in the content of bones and boneless meat (Table 4).

Table 4. Results of semi-carcass boning.

\begin{tabular}{|c|c|c|c|c|}
\hline \multirow{2}{*}{ Indicators } & \multicolumn{2}{|c|}{ Group 1 } & \multicolumn{2}{c|}{ Group 2 } \\
\cline { 2 - 5 } & $\mathrm{kg}$ & $\begin{array}{c}\% \text { to } \\
\text { semi- } \\
\text { carcass } \\
\text { weight }\end{array}$ & $\mathrm{kg}$ & $\begin{array}{c}\% \text { to } \\
\text { semi- } \\
\text { carcas } \\
\text { s } \\
\text { weight }\end{array}$ \\
\hline $\begin{array}{c}\text { Average chilled semi- } \\
\text { carcass weight }\end{array}$ & $119.26 \pm 1.24$ & 100 & $104.89 \pm 1.09$ & 100 \\
\hline $\begin{array}{c}\text { Produced from boning: } \\
\text { boneless meat }\end{array}$ & $94.34 \pm 0.93$ & 79.10 & $84.44 \pm 0.87$ & 80.51 \\
\hline bones & $20.87 \pm 0.59$ & 17.50 & $16.79 \pm 0.49$ & 16.00 \\
\hline tendons & $4.05 \pm 0.21$ & 3.40 & $3.66 \pm 0.19$ & 3.49 \\
\hline
\end{tabular}

Table 5. Weight and morphological composition of individual carcass cuts.

\begin{tabular}{|c|c|c|c|c|c|}
\hline \multirow[b]{2}{*}{ Cuts } & \multirow[b]{2}{*}{$\begin{array}{l}\text { Weight } \\
(\mathrm{kg})\end{array}$} & \multirow{2}{*}{$\begin{array}{c}\text { To } \\
\text { semi- } \\
\text { carcass } \\
\text { weight } \\
(\%) \\
\end{array}$} & \multicolumn{3}{|c|}{ Cut content $(\%)$} \\
\hline & & & $\begin{array}{c}\text { boneless } \\
\text { meat }\end{array}$ & bones & tendons \\
\hline \multicolumn{6}{|c|}{ Group 1} \\
\hline Neck & 10.69 & 8.9 & 82.1 & 13.7 & 4.2 \\
\hline $\begin{array}{l}\text { Scapulohumeral } \\
\text { part }\end{array}$ & 20.42 & 17.2 & 78.1 & 18.4 & 3.5 \\
\hline Dorsal part & 37.91 & 31.8 & 77.5 & 20.8 & 1.7 \\
\hline Saddle & 11.32 & 9.5 & 82.9 & 11.6 & 5.5 \\
\hline Hip & 38.92 & 32.6 & 79.3 & 16.6 & 4.1 \\
\hline
\end{tabular}


Table 5. Continued.

\begin{tabular}{|c|c|c|c|c|c|}
\hline Neck & 9.54 & 9.2 & 85.3 & 12.3 & 2.4 \\
\hline $\begin{array}{c}\text { Scapulohumeral } \\
\text { part }\end{array}$ & 18.28 & 17.4 & 79.5 & 16.9 & 3.6 \\
\hline Dorsal part & 32.30 & 30.8 & 78.6 & 19.5 & 1.9 \\
\hline Saddle & 10.94 & 10.4 & 83.1 & 9.9 & 7.0 \\
\hline Hip & 33.83 & 32.2 & 80.7 & 15.3 & 4.0 \\
\hline
\end{tabular}

The difference in the content of bones in the carcasses is consistent with the differences in the constitution of animals. The first group bulls, being higher-legged, produced carcasses with a higher bone content (by $4.08 \mathrm{~kg}$ ) during slaughter compared to the second group. In the first group carcasses, there was $4.52 \mathrm{~kg}$ of boneless meat per $1 \mathrm{~kg}$ of bones, while in the second group carcasses $-5.03 \mathrm{~kg}$. However, in general, when boning the first group semi-carcasses, more boneless meat was obtained, by $9.9 \mathrm{~kg}$ or $11.72 \%(\mathrm{P}>0.99)$, compared with the second group.

The study of the relative weight of the carcass individual parts did not reveal significant differences between the groups (Table 5).

Differences in the ratio of individual cuts to carcass weight were very small. Boning of each cut separately showed that the cut weight of the first group carcasses, as well as the carcases as a whole, contains more bones than the second group.

\section{Conclusion}

The bulls from stud bulls of a large type surpassed bulls from parents of a small type in meat production, which was reflected in a higher growth rate and better feed pay with an increase in live weight. At the age of 18 months, bulls from large-type parents reached a weight of $442 \mathrm{~kg}$, and from small ones - $413 \mathrm{~kg}$. These differences are statistically significant $(\mathrm{P}>0.99)$.

Small-type animals were distinguished by a more pronounced meat type of constitution. They were relatively low-legged and broad-bodied, with more thigh completeness. In the first group carcasses, there were $4.52 \mathrm{~kg}$ of boneless meat per $1 \mathrm{~kg}$ of bones, while in the second group carcasses - $5.03 \mathrm{~kg}$. However, in general, when boning semi-carcasses of the first group, more boneless meat was obtained, by $9.9 \mathrm{~kg}$. or by $11.72 \%(\mathrm{P}>0.99)$ compared with the second group.

\section{References}

1. R. G. Iskhakov, V. I. Levakhin, M. G. Titov, Animal science, 3, 22-25 (2007)

2. V. Kulintsev, M. Shakhmurzov, A. Shevkhuzhev, et al., J. of Engineer. and Advan. Technol. (IJEAT), 9(1), 2249-8958 (2019)

3. S. E. Andresen, C. L. Goad, L. Kriese-Anderson, et al., Animal Sci, 35(1), 57-65 (2019)

4. D. A. Randelin, V. V. Randelina, I. S. Bushueva, Bulletin of meat cattle breeding, 1(60), 244-247 (2007)

5. V. A. Pogodaev, V. V. Golembovsky, V. I. Komlatsky, L. F. Velichko and L. I. Konkov, IOP Conf. Series: Earth and Environ. Science, 624, 012134 (2021)

6. P. A. C. Luz, C. Andrighetto, et al., Effect of integrated croplivestock systems in carcass and meat quality of Nellore cattle Livestock Sci., 220, 83-92 (2019) 
7. V. V. Onishchenko, N. S. Dega, F. H. Bostanova, Int. J. of Humanities and Natural Sciences, 1(1), 29-35 (2019)

8. V. A. Pogodaev, A. N. Arilov, A. I. Petenko, A. A. Soldatov, T. I. Pakhomova, Research J. of Pharmaceutical, Biological and Chemical Sciences, 9(4), 766-759 (2018)

9. M. V. Tarasov, V. M. Gabidulin, V. Yu. Shmakov, Vestnik myasnogo skotovodstva, 63 (3), 71-76 (2010)

10. M. Tofastrud, A. Hessle and Y. Z. B. Rekdal, Weight gain of free-ranging beef cattle grazing in the boreal forest of south-eastern Norway Livestock Sci., 2 (2020)

11. L. I. Kibkalo, V. V. Bychkov, Bulletin of the Kursk State Agricultural Academy, 1, 70$71(2010)$

12. A. M. Pardo, M. A. Elzo, L. T. Gama and L. M. Melucci, Genetic parameters for growth and cow productivity traits in Angus, Hereford and crossbred cattle Livestock Sci., 233, 103952 (2020)

13. M. J. D'Occhio and P. S. Baruselli, Giuseppe Campanile, Influence of nutrition, body condition, and metabolic status on reproduction in female beef cattle, 125, 277-84 (2019)

14. A. Kucherenko, Animal breeding in Russia, 3, 6-7 (2009) 